\title{
W. E. B. DU BOIS'S CONTRIBUTIONS TO U.S. ECONOMICS (1893-1910)
}

\author{
Robert E. Prasch \\ Department of Economics, Middlebury College
}

\begin{abstract}
As a graduate student, Du Bois studied with two of the most important figures within what is today remembered as the German historical school of economics-Gustav Schmoller and Adolf Wagner. By taking seriously Du Bois's early ambitions in the field of economics, and rereading his early work as a social scientist in the context of early twentieth-century economic thought, the following article makes the case that Du Bois should be credited with having made several important contributions to U.S. economics. The article suggests that our failure to remember Du Bois as an economist is a joint consequence of two independent causes. The first is the racist attitudes of the U.S. academy of his time that simply would not accept a highly qualified African American as a colleague. The second is the sweeping changes that have so profoundly modified the method, form, and substance of U.S. economics over the past century.
\end{abstract}

Keywords: Du Bois, Race and Economics, History of American Economic Thought

As things are, our opinions upon the Negro are more matters of faith than knowledge. Every schoolboy is ready to discuss the matter, and there are few men that have not settled convictions. Such a situation is dangerous. Whenever any nation allows impulse, whim or hasty conjecture to usurp the place of conscious, normative, intelligent action, it is in grave danger. The sole aim of any society is to settle its problems in accordance with its highest ideas, and the only rational method of accomplishing this is to study those problems in the light of the best scientific research.

-W. E. B. Du Bois, "The Study of the Negro Problems," Annals of the American Academy of Political and Social Science (1898b, p. 10)

\section{INTRODUCTION}

\section{Du Bois and the German Historical School of Economics}

The above epigraph is representative of the perspective taken by Du Bois during his early years as a social scientist. Du Bois himself affirms this in his autobiography, describing his outlook as a young academic: 
The Negro problem was in my mind a matter of systematic investigation and intelligent understanding. The world was thinking wrong about race, because it did not know. The ultimate evil was stupidity. The cure for it was knowledge based on scientific investigation (Du Bois [1968] 2007, p. 124).

Today, such ideas concerning the relationship between knowledge and reform are usually associated with the Progressive Era. But this could not have been their inspiration, since Du Bois's academic career began before that movement in ideas. The origins of these ideas, and the approach to social scientific research and reform that follows from them, must have had another source. This source, the record suggests, can be traced to two of Du Bois's former professors, Gustav Schmoller and Adolf Wagner, who were themselves the two most prominent figures then associated with the younger generation of the German historical school of economics-a nineteenth-century movement in political economy that by the 1890 s was centered at the Friedrich-Wilhelm University in Berlin (now the Humboldt University of Berlin). This school of German scholars, which included economists and statisticians among its membership, also formed the nucleus of the policy research group Verein für Sozial-politik (the "Association for Social Politics," founded by Schmoller in 1873). The purpose of the Verein was to develop enlightened economic policies grounded on carefully conducted empirical, statistical, and historical scholarship. Its agenda was to facilitate the creation of a more modern and just German economy and society.

His biographers recount how W. E. B. Du Bois pursued, and came close to acquiring, a PhD in political economy at the Friedrich-Wilhelm University (Lewis 1993, chapter 6). This was consistent with the plan of study sketched in Du Bois's initial application to Harvard in 1887: "I wish to pursue at Harvard a course of study for the degree of $\mathrm{PhD}$ in political science after graduation. . . . I expect to take the special field of Political Economy" (Du Bois [1903] 1999, p. 187). His proposed final degree was to be in political science, as Harvard did not then have a $\mathrm{PhD}$ in economics. Upon completing a second bachelor's degree and two years of graduate study at Harvard, Du Bois continued his education with three semesters of study in Berlin, where he was fortunate to be accepted into the research seminars of Gustav Schmoller and Adolf Wagner, who undertook to supervise his doctorate. He also participated in Schmoller's Verein (Barkin 2000; Boston 1991; Broderick 1958; Edwards 2006; Lewis 1993, chapter 6; Schafer 2001).

At the time of Du Bois's residency in Berlin, the German historical school of economics was at the peak of its influence both within Germany and among the many young Americans who traveled there for advanced studies in economics and social science more generally (Dorfman 1955; Rodgers 1998, chapter 3). The attitude of many of these German-educated American economists, imbued with the ideas and ethos of the historical approach, is conveyed by one of the school's more ardent proponents: "The younger men in America are clearly abandoning the dry bones of orthodox English political economy for the live methods of the German school" (Ely 1883, p. 235). ${ }^{2}$ After a review of the statements Du Bois made when in Germany and later, Kenneth Barkin concludes that "there is much evidence that his professors in Berlin were critical contributors to the strategy he embraced to mitigate racism in the United States for at least a decade, from his return in 1894 until 1910" (Barkin 2000, p. 80; see also Boston 1991; Edwards 2006; Schafer 2001). ${ }^{3}$

Today Du Bois is remembered as an early sociologist, even as the founder of the first U.S. school of sociology (Gabbidon 1999). This interpretation will not be contested. What will be argued here is that if we interpret "economics" in a manner 
similar to that of the young Du Bois and his Berlin professors, some new and interesting insights come into view. To that end, the next section of this paper will briefly highlight some of the important premises and positions of the German historical school of economics so that the reader can better understand how Du Bois and his young American student colleagues would have understood the terms economics and economic research. The third section will draw upon Du Bois's published scholarship on economic issues to enumerate his several contributions to U.S. economics-again, if the latter term is identified, as I believe it should be, in a manner consistent with the methodological tradition within which $\mathrm{Du}$ Bois was working. The final section highlights Du Bois's rejection of the then-consensus understanding of the causal sequence between political rights and economic achievement.

\section{ECONOMICS AT BERLIN: THE GERMAN HISTORICAL SCHOOL}

Regrettably, Du Bois is not remembered as an economist. But the reason cannot be attributed to the residency and funding difficulties that prevented his completion of a $\mathrm{PhD}$ in Berlin (upon his return to the United States his old advisor, Albert Bushnell Hart, arranged for Du Bois to finish a PhD in history from Harvard). After all, many well-known and highly regarded economists never completed a doctorate in economics. The reason Du Bois is not thought of as an economist is a joint consequence of the entrenched racism that frustrated his academic ambitions and important changes in the method, form, and content of U.S. economics. By the time Du Bois passed away in the 1960s-at which time his life became the proper subject of historians and biographers-academic economics had undergone such profound changes that today's social scientists routinely perceive the economists of the German historical school to be either "economic historians" or "sociologists." To correct this misunderstanding, and thereby restore Du Bois's early scholarship to its place within the history of U.S. economics, it will be necessary to begin by reviewing four of these changes.

First, in the 1890s, economics at Berlin was a significantly more empirical and methodologically inductive discipline than either its English or U.S. counterparts (Bonar 1963). Additionally, economics has come to be closely-and in the United States almost exclusively-identified with the neoclassical school of economists. The neoclassical school uniquely presumes or posits a primordial and universal condition of "scarcity," a commitment to methodological individualism, and an insistence that all economic theorizing be reduced to a form featuring rational and self-interested individuals facing a "constrained choice." Such changes may or may not represent an improvement over earlier approaches, but what is not subject to dispute is that today's economics is built upon methodological tendencies and presumptions that Adolf Wagner and especially Gustav Schmoller resisted throughout their careers.

The gulf between the historical and neoclassical schools of economics was especially evident in their respective attitudes toward mathematical modes of presentation. While this is not widely understood or appreciated, it was by shedding historical specificity and ignoring the socially embedded nature of individuals that Neoclassical economics was able to develop and refine its mathematical form of presentation. By way of contrast, consider Adolph Wagner's derogatory comment-in an otherwise favorable review_of the formulae and graphs in Alfred Marshall's Principles of Economics (1890): "I do not believe that this mode of treating the subject has an independent value of its own for solving our problems" (Wagner 1891, p. 327). ${ }^{4}$ 
Contrary to what they saw as a strong a priorism, Du Bois's Berlin professors believed that a scientific approach to economics should begin with an examination of the facts concerning an economy's structure. This included a clear understanding of the history and the current state of an economy's laws, institutions, and norms. ${ }^{5}$ To support such a research program, the political economy faculty of the FriedrichWilhelm University was among the first to feature courses in statistical methods. These were taught by Professor August Meitzen, who was an assistant to the distinguished economic statistician Ernst Engel of the Royal Statistical Bureau of Prussia. ${ }^{6}$ In sum, while Du Bois's professors did not eschew theory, they did think that the quest for a universal theory of economics was misguided. In their view, no one economic theory could be applicable to all societies over all times and places (Mote 1997; Schmoller 1894; Sombart [1929] 1991).

Second, economists of the historical school believed that the most appropriate unit of analysis was the social group. Depending upon the problem under consideration, the identity and size of groups could and would vary. Explicitly rejected was the individualism that was a cornerstone of what they derisively labeled the Manchester or English approach to economics. The reason for this position was that Du Bois's professors believed that individuals were constituted by their social relationships and, in particular, by the institutional and normative structures of the society and economy in which they were living and working:

The fundamental idea that pervades and gives unity to Wagner's economic system is the "social" idea. Analyzing the history of the development of economic thought, he sees, on the one hand, the system of individualism, dating back to the Physiocrats and Adam Smith, the fundamental tenet of which is the "laissez faire" doctrine; on the other, the doctrines of the socialists and communists, representing a timely reaction from the individualism of the classical school, but, as is usual with reactions, going too far to the other extreme. The standpoint of socialism he accepts as the only rational standpoint, i.e., the good of the community, of society, must be the starting point in political economy, and not the good of the individual or of any group of individuals (Seager 1893, p. 243; emphasis in the original).

Third, as is evident from the above quotation, Du Bois's professors were critical of a perceived bias toward laissez-faire in "Manchester" economics. In their view government policies constructed upon such a deeply flawed theory contributed to inequality, poverty, and political strife. For that reason they found that approach to political economy to be unjust, unethical, and even unchristian (Ely 1883; Rodgers 1998, chapter 3; Schafer 2001; Schmoller 1894; Small 1924). In contrast to their English and U.S. peers, Du Bois's professors envisioned a prominent role for the state in directing or guiding the nation's economic affairs. Their proposals included unemployment insurance, extensive labor legislation, an income tax, and trade protection (Barkin 2000).

In light of these views, Wagner and Schmoller were comfortable with their opponents' accusation that they were "socialists of the chair." This moniker was to some degree appropriate, as theirs was a socialism that was grounded in neither working-class mobilization nor revolutionary ideology. Rather, their reforms were premised upon a benevolent centralized polity, one dedicated to ameliorating the damage caused by rapid industrialization and urbanization while simultaneously dedicated to the creation of a modern and ethically defensible economy. Today we might be bemused by a "socialism" that could be supported by the chancellors of late 
nineteenth-century Germany. However, the reason for this support is not hard to discern. The perception, or at least the hope, was that it would erode working-class support for the rapidly emerging Social Democratic Party (Craig 1978, chapter 5).

As mentioned, this German vision of an activist polity, one based on the most advanced ideas of economics and empirical social science, appealed to a generation of U.S. students (including Du Bois, whose graduation oration at Fisk College was on the subject of Bismarck). Upon returning to the United States, a substantial number of these young U.S. scholars took up careers as academics or researchers with state labor bureaus or tariff commissions, or as activists in college settlements. Collectively, they formed an important and prominent constituency of the Progressive movement, with its characteristic effort to draw upon science and expertise to reform the perceived shortcomings of plutocracy and unregulated market capitalism (Rodgers 1998).

Additionally, studies in Germany were most of these students' first exposure to the idea that economics could be a vibrant discipline combining empirical studies with spirited methodological and theoretical debate. The contrast with the then widely perceived moribund state of U.S. academic economics could not have been stronger (Bonar 1963; Leslie [1880] 1888; Dorfman 1934, chapters 2-3; Ely 1883; Furner 1975; Seager 1893). ${ }^{7}$ Historian Daniel Rodgers points to the importance of this widely shared educational experience for the growth of U.S. social science:

But the German university connection had, in truth, lasting historical consequences-not only for the sleepy American colleges that it transformed but also for transatlantic social politics itself. It knocked the provincial blinkers off a cadre of young Americans and gave them a lasting sense of participation in an international movement of intellectual and political reform. It fired them with policy-making ambitions and new, borrowed models of public influence (Rodgers 1998, p. 77; see also Dorfman 1955). ${ }^{8}$

Fourth, Du Bois and his professors rejected, even as an ideal, the objective of a "value-free" economics. Lewis Gordon summarizes one element of this objection: "It is only the powerful who can afford a world devoid of value since they are already situated in a position to be its beneficiary" (Gordon 2000, p. 278). Schmoller, for example, argued that economic progress and social justice emerge together as each new economic formation brings its own ideal and understanding of social justice into existence. He argued that the emerging content of economic justice may, initially, be difficult to discern (Schmoller 1894). Nevertheless, it could and should be uncovered in the course of analysis:

In the eyes of the historical school, only the close observation of actual conditions of production and exchange could enable the scholar to understand the laws of development of the social organism, allow him to apprehend new ideals of justice, and provide a solid grounding for the formulation of an interventionist social and economic policy (Schafer 2001, p. 935).

However, Wagner and Schmoller were not of one mind as to how these new policies and programs were to come about. Wagner took an activist approach and was often directly engaged in political affairs, even standing for elected office (Barkin 1969). Schmoller thought that it was sufficient to present state officials and the public with detailed scientific studies supporting coherent and just policies. Kenneth Barkin argues that upon his return to the United States Du Bois adopted Schmoller's 
approach. Schmoller, of course, had the pleasure of seeing the Prussian state adopt several policies that began as Verein research papers. Du Bois's experience, as we know, could not have been more different. Frustrated in his efforts to attract funding for his research, and alarmed at the deteriorating political situation confronting African Americans, Du Bois was increasingly aware that substantive change would require more than compelling presentations before prominent academic audiences (Barkin 2000, pp. 93-96; Du Bois [1968] 2007, chapters 13-14).

In addition to his strong personal commitments, during these early years Du Bois's investigations into economic questions were encouraged by two established sources. The first was Schmoller's Verein, which had a preexisting interest in studies of agriculture and peasant communities (Rodgers 1998, p. 321). Perhaps with this end in view, Du Bois's professors encouraged him to write his doctoral thesis on the rural economy of the southern states, most likely with an eye to uncovering similarities to and contrasts with German agricultural regions and its economic condition and practices (Edwards 2006, p. 405; Lewis 1993, pp. 136-142).

Another important impetus came from an overlooked figure in the history of U.S. economics-Carroll D. Wright (Dorfman 1955, pp. 21-22). From the time Wright took over the Federal Bureau of Labor he was interested in, but faced political obstacles to, conducting studies of the economic conditions and prospects of African Americans. Finally obtaining the necessary permission during the McKinley administration, Wright published Du Bois's "The Negroes of Farmville, Virginia: A Social Study," and promoted it to others as a model for researchers to follow (Du Bois 1898a). With this initial success, Wright encouraged Du Bois and several other scholars to conduct and publish similar studies with the bureau (Du Bois 1901, 1899; Grossman 1974).

\section{DU BOIS'S CONTRIBUTIONS TO ECONOMICS}

The first, and in many ways the most original, of Du Bois's several empirical studies of African American communities in Philadelphia and elsewhere began with the premise that African Americans were fully constituted persons. While several academic studies of African Americans had previously been conducted, Du Bois's were virtually unique in not treating African Americans as a population with innate and perhaps permanent individual failings (Cherry 1976; Dimand 2005; Prasch 2004). Indeed, he boldly asserted - in a publication jointly sponsored by the University of Pennsylvania and the American Academy of Political and Social Science-that "Negro problems are problems of human beings" (1899, p. iv). At the same time, Du Bois was able to reinforce the perspective of both his German professors and what was then called the scientific charity movement, asserting that "until he has prepared the ground by intelligent and discriminating research, the labors of philanthropist and statesman must continue to be, to a large extent, barren and unfruitful" (Du Bois [1899] 1973, pp. iv-v). ${ }^{9}$

Second, Du Bois emphasized the importance of the economic context and environment within which African Americans sought opportunity and advancement (Du Bois 1898b; Edwards 2006, pp. 413-416). In each of his early economic investigations, Du Bois discussed discrimination and how it had shaped the range of economic options and outlooks of African Americans. In his chapter "The Occupation of Negroes" in The Philadelphia Negro ([1899] 1973), he presented discrimination as a factor inhibiting upward mobility, thereby stifling legitimate ambition. While it may be obvious, it should nevertheless be stated that his analyses of discrim- 
ination, based as they were on direct observation, were substantially more insightful than what was then circulating in the popular and academic literature. For example, he could formulate compelling answers to questions such as why it was that educated African Americans were making more progress as doctors than as lawyers, or why African Americans were turning away from what appeared to be substantial opportunities as barbers (Du Bois [1899] 1973, chapter 9).

Du Bois, in the best traditions of the historical school of economics, also emphasized the role of prior conditions in shaping the economic capacities and performance of African Americans. Consider the following remark from his Bureau of Labor study on landholding trends among freedmen in postbellum Georgia:

By 1870 [the freedman] was left to shift for himself amid new and dangerous social surroundings. No such curious and reckless experiment in emancipation has been made in modern times. Certainly it would not have been unnatural to suspect that under the circumstances the Negroes would become a mass of poverty-stricken vagabonds and criminals for many generations, and yet this has been far from the case (Du Bois 1901, p. 648).

To Du Bois, the previous abuses associated with slavery and the current practice of discrimination each and jointly left African Americans with formidable competitive obstacles. To illustrate the importance of these institutionally created disadvantages, Du Bois neither glossed over nor ignored difficulties and deficiencies that he perceived among those discriminated against. Indeed, his assessments were sometimes blunt: "That the average Negro laborer today is less efficient than the average European laborer is certain" (Du Bois 1906, p. 225; see also Du Bois [1899] 1973, pp. 97-98, 133-134). At these moments, Du Bois sounded like Booker T. Washington in stressing the role that illiteracy and ignorance, and especially ignorance of sound agricultural processes, played in inhibiting the economic development of the African American community (Du Bois [1903] 1999, chapter 6; 1898b; [1899] 1973; 1906). Where these two differed was on the cause of these disadvantages, their meaning, and the way forward.

Du Bois's third contribution to U.S. economics was his method. As Barrington Edwards so ably illustrated in a recent essay, Du Bois stayed close to the empirical methods he and so many others-who Richard Ely thought of as the "new" or "younger" generation of U.S. economists-had learned in Germany (Edwards 2006; Ely 1883). The reason, of course, was that he shared their belief that improved empirically driven scientific knowledge would—pace Schmoller-reform society toward a more economically effective and socially just order. To this end, he considered it his duty to provide detailed, unvarnished, and empirically based representations of the economic conditions of African Americans. The several empirical studies that $\mathrm{Du}$ Bois wrote during these years for the University of Pennsylvania, the Bureau of Labor, and Atlanta University are all marked by his view that distorting or repressing our knowledge of the particulars of the African American condition in the Whitedominated United States would be poor social science. Inevitably, sooner or later, such practices would also harm the cause of social progress (Du Bois 1898b; Edwards 2006; Grossman 1974; Lewis 1993, chapters 8 and 9).

But, specifics aside, what must be emphasized is both the novelty and sometimes even the controversy provoked by these methods in the U.S. context. Although Du Bois was ignored by many established U.S. social scientists, his successful deployment of what were then considered the most modern techniques and his resulting publications nevertheless contributed to the emergence of this rather self-conscious "new genera- 
tion" of economists and empirical social scientists. Within a decade of the appearance of The Philadelphia Negro ([1899] 1973), the method of the "social survey" was on its way to being established as "best practice." A prominent example was the widely acclaimed Pittsburgh Survey, funded by the Russell Sage Foundation and conducted under the direction of Paul Kellogg in 1907-1908. But there is little doubt that Du Bois was a pioneer of this approach. When he published his study of Philadelphia, the only significant precedents in the English-speaking world were studies conducted by Charles Booth in London and Hull House in Chicago (Sklar 1998). ${ }^{10}$

To summarize, in The Philadelphia Negro: A Social Study ([1899] 1973) and his several publications with the Bureau of Labor, we see methods deployed that are consistent with the empirical and comparative approach of the German historical school of economics. Also present, if only by implication, is Du Bois's rejection of another approach to economic research, one based on what his Berlin professors thought of as an overdependence upon a priori principles. Consequently, the policy recommendations that flowed from these studies could claim to be based upon detailed fieldwork. In a contemporaneous article that explicitly addressed research methods, Du Bois highlighted the importance of carefully applying empirical methods: "The one positive answer which years of research and speculation have been able to return is that the phenomena of society are worth the most careful and systematic study" (Du Bois 1898b, p. 1).

Fourth, Du Bois was one of the few social scientists of his era to address the specific qualities of the regime of "free contract" in the postbellum southern states. Stated briefly, southern law and social practices combined to make it exceptionally difficult to exit sharecropping, labor, or debt contracts. One could not quit until a variety of conditions were met, with their fulfillment almost always unilaterally determined by the (White) landlord, employer, or creditor. Moreover, as a consequence of discrimination and southern understandings of "law," a sharecropper, employee, or debtor rarely had recourse to independent arbitration or dispute resolution. ${ }^{11}$ It was, after all, no secret that the racial politics of the South meant that the (White) landlord, employer, or creditor could count upon the openly partisan support of the sheriff and judiciary. These, of course, could be and often were supplemented by other varieties of nonjudicial punishment, up to and including lynching. Summarizing these issues, Du Bois was highly critical of the nature and quality of contracting in the South:

The system of farm tenancy as practiced over the larger part of the south today is a direct encouragement to cheating and peonage, a source of debauching labor, and a feeder of crime and vagrancy. It demands for its support a system of mortgage and contract laws and a method of administration which are a disgrace to 20th century civilization, and for every man which the system has helped into independence it has pushed ten back into slavery (Du Bois 1906, p. 237).

Du Bois's criticism of "free contract" pointed to the particulars of the broader context in which all contracts were negotiated and enforced. He understood, as few other economists did, that the problem was embedded in the specific qualities of the social system:

The contract labor laws, the vagrancy laws, the permissible debt manipulation by book accounts, and the discredited "company stores system" make a body of law which carries force and fraud on its very face and which covers a large part of the rural South (Du Bois 1912, pp. 81-82). 
The underlying cause of these oppressive institutions was not mysterious:

Every one is, of course, aware that the reason that the South is building industry so largely on compulsory labor, ignorance, discrimination in the courts, lack of organized justice, and disfranchisement is because these weapons are excused by the Negro problem (Du Bois 1912, p. 81).

Du Bois understood, and long experience and economic theory both affirm, that peonage contracts reduce workers' incentive to work hard or creatively. Consequently, they reduce the productivity of labor. Less productive labor means that, all things being equal, investments in land, machinery, and other improvements are also less productive and remunerative (Ransom and Sutch, 2001, chapter 8). For these reasons, as Du Bois reminded his audience at the American Statistical Association in 1911, "any student of economics" could understand that these contracts were a significant problem (Du Bois 1912, p. 80).

Fifth, Du Bois observed a trend that contributed to his formulation of a strategy for economic and social progress that would become increasingly prominent in his academic and popular writing. This was his proposal that African Americans should embrace "economic cooperation"-that is to say, a strategy wherein the African American community turns to itself to meet its needs and cultivate its economic capacities and potential. He believed that several benefits would follow from such a response to pervasive discrimination. These included economic independence, economic security, and even the beginnings of genuine prosperity (DeMarco 1974; Du Bois 1906, pp. 234-236; Reed 1985, pp. 432-438).

Even here the strong influence of group attraction is being felt, and Negroes are beginning to patronize either business enterprise conducted by themselves or those conducted in a manner to attract their trade. Thus, instead of the complete economic dependence of blacks upon whites, we see growing a nicely adjusted economic interdependence of the two races, which promises much in the way of mutual forbearance and understanding (Du Bois 1898a, p. 34).

In these early economic studies, this vision of what he was then calling the "group economy" was presented as a strategy for economic development, and specifically for the purchase of land. ${ }^{12}$

The demonstrated usefulness, and even greater potential, from economic cooperation within and among African American communities was one of Du Bois's most important points of optimism at this time. The reason was that in the early 1900s most southern African Americans worked in agriculture, and in a number of instances where it was tried, cooperation in financing the purchase and improvement of land was an important precedent, one that pointed to economic independence and advancement for masses of people. Du Bois was especially encouraged by the successful application of this strategy in Lowndes County, Alabama (Du Bois 1906). He argued, on the basis of his own observations, that those districts that featured greater land ownership on the part of African Americans also enjoyed a superior quality of life. This was evident in better homes and improved schooling (Du Bois 1906, pp. 234-236).

Before leaving the subject of agriculture we should note that, by contrast to what was then passing for the conventional wisdom, Du Bois did not believe that the slavery experience had endowed African Americans (or Whites, for that matter) with an understanding of modern or efficient agricultural processes. To Du Bois the slave economy was uniquely dysfunctional, as it was built upon both an artificially low cost 
of labor and the ready availability of unexhausted land to the West. He thought, correctly, that agricultural methods based upon such preconditions were wasteful of both labor and land. We already know Du Bois's views on the abuse of African American labor under sharecropping and tenancy. Similarly, Du Bois used the phrase "land-murder" to describe the slave owners' stewardship of the land. He further quipped that "no graduate of that school knows how to make the desert bloom and the process of teaching must be long and tedious" (Du Bois 1906, p. 231). As for its cultural legacy, Du Bois thought that slavery left African Americans weakened because they were "a people who for generations have been trained to shirk work" (Du Bois [1899] 1973, pp. 98-99; see also Prasch 2004).

Du Bois believed that besides promoting extra-market institutions to facilitate the ownership and development of farmland, the African American community should pursue economic cooperation as the best available means for nurturing its own professional class. He also believed that such a class, though numerically small, would be more than merely economically important. Besides providing an avenue for the upward mobility of the "talented tenth," the role of this emerging professional class would be to provide capable leadership and direction for the African American community as a whole. Du Bois was, of course, aware that this would not be a democratic leadership (Du Bois [1907] 1969, p. 11). Nevertheless, this was the best available option, as the default was continued reliance on local White leadership. The increasingly hostile and downright murderous attitudes of this latter group since the political compromise that ended Reconstruction said all that needed to be said on the viability of the default approach.

As with land ownership, Du Bois understood that the hostility to be expected from surrounding White communities would impede the emergence of an African American professional class (Du Bois 1906, pp. 230-231). An additional barrier was the established market share and hence greater patronage enjoyed by the Whites already dominant in most professions. While this is speculative, Du Bois's analysis and his proposed solution parallel, at least implicitly, Schmoller's depiction of the challenges facing newly industrializing nations (such as Germany) competing with established industrialized nations (such as Great Britain). In each instance, the solution proposed was to create a protected sphere, one that would be temporary, to enable the newer economy to establish itself before entering into the larger, more competitive economic fray (Du Bois 1906, pp. 223-224; for Schmoller on trade issues see Taussig 1905).

The sixth of Du Bois's contributions to U.S. economics was the example he set. He demonstrated, undoubtedly to the consternation of many, that an African American could conduct modern social scientific research at the highest level, and could do so with unmistakable success. Of course resistance to new people, especially those with new ideas, takes well-known forms. One is to simply ignore them. Du Bois was duly ignored when, after his initial successes, he received no offers of employment from a prominent research university. He was also unable to gain a permanent position with the Federal Bureau of Labor. Worse yet, after Carroll Wright's retirement the sole copy of what Du Bois considered to be his best and most in-depth study, "The Negroes of Lowndes County," was destroyed by the Bureau's staff. The new director also ceased funding studies of African Americans (Du Bois [1968] 2007, p. 144; Grossman 1974). Despite these multiple obstacles, Du Bois's scholarship was noticed, and it clearly established a new standard (Katz and Sugrue, 2001). Moreover, the methods that Du Bois deployed in Philadelphia and for the bureau became the prototype for studies he later conducted or supervised when he took up his new position as Professor of Economics and History at Atlanta University. 


\section{CIVIL RIGHTS AND ECONOMIC PROGRESS}

We now turn to the seventh and, in hindsight, most important recurring theme in Du Bois's early scholarship on the economic condition of African Americans. This was his identification of the deleterious, even disastrous, effects of political disenfranchisement on African American economic progress (Du Bois [1899] 1973, chapter 17; Du Bois 1901). As he stated in The Souls of Black Folk:

To leave the Negro helpless and without a ballot to-day is to leave him, not to the guidance of the best, but rather to the exploitation and debauchment of the worst; that this is no truer of the South than of the North,- - of the North than of Europe: in any land, in any country under modern free competition, to lay any class of weak and despised people, be they white, black, or blue, at the political mercy of their stronger, richer, and more resourceful fellows, is a temptation which human nature seldom has withstood and seldom will withstand (Du Bois [1903] 1999, pp. 112-113).

This theme was forcefully reiterated in his presentation to the American Economic Association. This paper is important because of the prominence of the audience he addressed, and because it is an overview and summary of the findings and implications of his several investigations into the economic and social condition of African Americans (Du Bois 1906). The emphasis on voting rights appears again in his address to the American Historical Association (Du Bois 1910), and in a short paper presented just after the close of the period under consideration here-his 1911 address to a joint session of the American Economic Association and the American Statistical Association (Du Bois 1912, pp. 83-84).

To fully perceive the originality of Du Bois's emphasis on the right to vote, let us recall that when U.S. economists and social scientists wrote on the subject of disenfranchisement, they almost always denigrated the political capacities and aspirations of African Americans. The few (and among White scholars they were few indeed) who believed that full male suffrage should and would eventually be granted to all African Americans, nevertheless thought that it would follow, not lead, their demonstrated success in the economic sphere.

A short paper by the soon to be prominent U.S. economist John Bates Clark is an excellent example of this latter perspective. Presenting his remarks to a distinguished conference of White scholars and dignitaries twenty-five years before the anthropologists Franz Boas and Alfred Kroeber published their pathbreaking papers on the essential similarity of all races, Clark observed that "a part of the difficulty lies, probably, in the Negro's psychology; but that is not so deeply rooted that it cannot be eradicated. It is not, at any rate, permanently in the blood" (Clark 1891, p. 95). Clark then foretold a day when southern African Americans (the Great Migration had yet to occur) would earn enough to purchase their own farms; compete as equals; and then, on the basis of this economic foundation, aspire to political equality with southern Whites:

I expect in due time to see the Negro brought to the polls in a coach and four rather than see him repelled. I expect to see fullest suffrage given to him before, from mere education, he is ready for it. . . The vote of the Negro who owns his farm will be a terror to nobody. It will be a source of safety to the republic as a whole (Clark 1891, p. 95). 
Du Bois never commented upon Clark's paper. But it is evident that by the turn of the century he fundamentally disagreed with the causal relationship it posited between economic achievement and political equality. In Du Bois's view political equality, and in the U.S. context this meant male suffrage on equal terms, was a precondition to establishing and maintaining the institutions required for economic advancement.

With hindsight, we can see that while Clark's paper was sympathetic to African American political aspirations, it was naïve in that it was published at the beginning of the movement to formally disenfranchise them. Despite these profound and disturbing events, the belief that economic success would provide the foundation for the eventual achievement of political equality remained a powerful idea. A prominent southerner who insisted on maintaining this vision was, of course, none other than Booker T. Washington. In his "Atlanta Compromise" speech, he famously concluded that "no race that has anything to contribute to the markets of the world is long in any degree ostracized" (Washington [1895] 1965).

In contrast to Clark and Washington (and, I should add, most economists who have considered the question since then), Du Bois believed that the political disenfranchisement of southern African Americans significantly reduced their economic capabilities and potential. Disenfranchisement impeded the building of necessary infrastructure, such as schools and roads, while obstructing the development of workable and just regimes of contract and property rights. Responding directly to Washington's program, Du Bois stated that "[Washington] is striving nobly to make Negro artisans business men and property-owners; but it is utterly impossible, under modern competitive methods, for workingmen and property-owners to defend their rights and exist without the right of suffrage" (Du Bois [1903] 1999, p. 41). It was also evident that the formal disenfranchisement of African Americans was further undermining the South's already tenuous relationship with "the rule of law." Indeed, in many of the social scientific works that he wrote during this period, including his published Harvard dissertation, Du Bois upended the then conventional narrative by stressing the economic and political significance of widespread lawlessness among southern Whites.

By the early 1900s, Du Bois had concluded that the absence of suffrage and other fundamental civil rights, including contract and property rights, represented an independent and significant force retarding the economic and social progress of African Americans. Moreover, his frustration was becoming increasingly evident, even in his scholarly writing. Consider the powerful rhetoric Du Bois deployed in his presentation before the American Economic Association when his paper turned to the subject of suffrage: "You can twist this matter up and down and apologize for it and reason it out - its wrong, and unjust, and economically unsound, and you know it" (Du Bois 1906, pp. 241-242).

Months after this paper was published by the American Economic Association, the Atlanta race riots occurred. For this and other reasons, Du Bois began to feel that the scholarly methods and lessons he had adopted during his years in Germany-that of examining the facts in all their detail and presenting them to scholars and the educated public-might be insufficient to overturn entrenched U.S. racism (Edwards 2006, pp. 217-218). Another approach would be required. In July 1910, Du Bois left behind his effort to establish himself as an academic in the mold of Gustav Schmoller, and joined the NAACP as the first editor of its journal, The Crisis. There he embarked upon a new phase of his life's work, one that would embody a more direct approach to challenging the color line (Du Bois [1968] 2007, chapter 15). 


\section{CONCLUSION}

Was, then, The Philadelphia Negro ([1899] 1973) an early and pathbreaking work in empirical sociology? What of the several studies on the economic conditions of African Americans published by Carroll Wright at the Bureau of Labor? I would say that they are-if we use language as it is today. But if we are to fully understand Du Bois and the evolution of his ideas, we must not lose sight of the fact that the methods he deployed in this early scholarship were those of the German historical school of economics. We must also recall that Du Bois, and his peers among the "new" or "younger" generation of U.S. economists and social scientists, considered these methods to be both modern and unimpeachably scientific. Each of Du Bois's social scientific studies also benefited from the tremendous imprimatur of coming from someone who had studied political economy at what was then widely held to be the world's most advanced institution for social scientific research-one that was the model for the graduate schools that were even then being assembled at Johns Hopkins, Columbia, and Cornell. Du Bois's early writings in economics carried the undeniable ethos of having been written by someone who had been a favored student of Gustav Schmoller and Adolf Wagner. Consequently, Du Bois's scholarship could not be denied on the basis that he was neither capable nor trained to undertake modern social scientific research. Unsurprisingly, his presentations to professional bodies such as the American Historical Association and the American Economic Association drew substantial audiences. But it was equally evident that many, if not most, U.S. social scientists could not accept his findings. But neither could they dismiss them on the grounds that the author or his published work failed to achieve the "best-practice" standards of modern social science. The message and its messenger simply had to be marginalized, and they were.

Corresponding author: Professor Robert E. Prasch, Department of Economics, Middlebury College, Middlebury, VT 05753. E-mail: rprasch@middlebury.edu

\section{NOTES}

1. I would like to thank Falguni A. Sheth, Mickaella Perina, and Bill Hart for their several suggestions and helpful comments. I would also like to thank the staff of Special Collections at the W. E. B. Du Bois Library at the University of Massachusetts, Amherst. Finally, I owe thanks to the student editors of the Middlebury College magazine Skindeep for organizing the symposia where an earlier and shorter version of this paper was initially presented.

2. The hundreds of Americans who studied political economy in Germany during the latter nineteenth century include many who would emerge as the most important economists of the early twentieth century. The just-quoted Richard Ely is joined by Simon Patten, John Bates Clark, Henry Carter Adams, E. R. A. Seligman, Frank Taussig, Arthur T. Hadley, Henry Farnam, Henry Rogers Seager, the Nobel laureate Emily Greene Balch, and many others. This list also includes several prominent figures who, after studying political economy in Germany, are remembered for distinguishing themselves in the then-emerging field of sociology. Albion Small, George Howard, Mary Kingsbury, Edward A. Ross, and Samuel McCune Lindsay are prominent figures on this latter list. In a manner parallel to that of the young Du Bois, Ross's and Lindsay's careers illustrate the fluidity of the boundary between economic research, as it was then conducted in Germany, and the scholarship that would, several decades later, come to take the name sociology in the United States.

3. Another American profoundly influenced by his studies in Germany and Austria was Henry Rogers Seager, who became a well-known economist and active promoter of labor legislation during a long career at Columbia University. While still in Europe he published a fascinating and detailed memoir that discussed, among other subjects, the intellectual milieu of Wagner's and Schmoller's lecture courses and seminars in Berlin (Seager 1893). For this 
reason Seager is a useful source for how this educational milieu was experienced by a young, smart, and ambitious American student - albeit not one who had to simultaneously negotiate the issue of race. As near as I can tell, Seager left Germany to continue his studies at the University of Vienna just as Du Bois was arriving in Berlin.

4. Readers should be aware that Wagner and Schmoller disagreed on a number of issues, including the value of the "marginalist" theory advanced by Carl Menger. However, since the point of this section is to draw attention to some of the aspects of their approach to economics that are distinct from today, and that also had an important influence on the young Du Bois, I am glossing over these differences in favor of positions they shared, even if they held them to different degrees.

5. "[Schmoller] points out that the three 'norms' of any society are its morals, its customs and its laws; these constitute the framework within which each of the social sciences must be built up" (Seager 1893, p. 249). This perspective would later become central to the approach of the American institutionalist school of economics that was dominant from approximately from 1910 to 1940 (Prasch 2007; Rutherford 2000; Yonay 1998).

6. This Royal Statistical Bureau was the ideal sought by Carroll Wright when he directed the Massachusetts Bureau of Statistics of Labor (1873-1878) and later the Federal Bureau of Labor beginning in 1884 (now the Bureau of Labor Statistics, or BLS). This German influence still resonates in the teaching of statistics and economic history to students of economics (although today the latter course is unlikely to be required).

7. The reader should note that my characterization is of academic economics. Political movements and popular writers of varying abilities and insights presented the U.S. public with a wide variety of perspectives on the economic issues of the day. By contrast the discussion within academic institutions was narrow, controlled, and domesticated. One reason was that academic freedom was not considered to be a virtue by the highly intrusive college trustees of this era and, for that reason, was not generally in evidence (Sinclair 1923).

8. Returning to the United States with new ideas and an inadequate commitment to laissez-faire induced a pressing need to discipline this generation of economists. Such discipline was soon forthcoming. The late nineteenth and early twentieth centuries featured many prominent dismissals of economists who had studied in Germany, in addition to a number of American-educated scholars who had been overly influenced by these "new" ideas (Cohen 2002, pp. 155-176; Furner 1975).

9. For an interesting survey of how Du Bois's Philadelphia study was received by scholars, see Katz and Sugrue (2001).

10. Scholars and biographers have often commented upon the implicit elitism of Du Bois's approach to social problems and policy analysis—and indeed, Du Bois himself was aware of this and commented on it in his autobiography. But it should be noted that his style was fairly typical of the ethos and outlook of the social reformers of both late nineteenthcentury Germany and the Progressive Era. Du Bois is, perhaps, exceptional for having lived so much longer than so many of his peers. Hence, a deportment that would have been less remarkable in the early twentieth century (at least among White social scientists) could be perceived to be somewhat idiosyncratic thirty, and especially fifty, years later. As to its substance, Adolf Reed, Jr., has presented a thoughtful and persuasive study of Du Bois's scholarly and political outlook that emphasizes its essential continuityalbeit a continuity marked by changing strategies (Reed 1985).

11. For a detailed discussion of the distinction between free contract and what we today consider to be free labor, along with a history of the evolution of the labor contract in English and American law, see Robert J. Steinfeld (2001). Unfortunately many of today's economists, and too many economic historians, do not understand these changes, or are inclined to downplay the substantial distortions they may present for the already-problematic neoclassical presumption that "free entry and exit" typifies market relations (Prasch 2006).

12. To clarify terms, in the early writings being examined here, Du Bois's use of the term economic co-operation was closer to the idea of buying from within a tightly knit community than to some vision of socialism: "[Group Economy] consists of such a co-operative arrangement of industries and services within the Negro group that the group tends to become a closed economics circle largely independent of the surrounding white world" (Du Bois [1907] 1969, p. 179). In other words, Du Bois's idea was that people, groups of people, or groups of firms could and should cultivate the habit of working more closely with one another as a means of developing their capacities independently of the hostile social environment in which they lived. This would enable them to develop bonds of trust, including formal or informal credit relationships, facilitate cooperative efforts to 
buy land, set up banks and insurance companies, sell or buy bulk commodities at advantageous prices, etc. In these early writings Du Bois did not use the term group economy as a euphemism for socialism. Rather, the term denoted a strategy to promote economic development in a profoundly segregated and racist South, where African Americans had little property and limited bargaining power.

\section{REFERENCES}

Barkin, Kenneth D. (1969). Adolf Wagner and German Industrial Development. Fournal of Modern History, 41(2): 144-169.

Barkin, Kenneth D. (2000). "Berlin Days," 1892-1894: W. E. B. Du Bois and German Political Economy. Boundary 2, 27 (3): 79-101.

Bonar, James (1963). German School of Political Economy. In Henry Higgs (Ed.), Vol. 3 (N-Z) of Palgrave's Dictionary of Political Economy, Rev. ed., pp. 196-206. New York: Kelley Reprints.

Boston, Thomas D. (1991). W. E. B. Du Bois and the Historical School of Economics. American Economic Review, 81(2): 303-306.

Broderick, Francis L. (1958). German Influence on the Scholarship of W. E. B. Du Bois. Pbylon Quarterly, 19(4): 367-371.

Cherry, Robert (1976). Racial Thought and the Early Economics Profession. Review of Social Economy, 34(2): 147-162.

Clark, John Bates (1891). The Industrial Future of the Negro. In Isabel C. Barrows (Ed.), Second Mohonk Conference on the Negro Question, pp. 93-101. Boston, MA: George H. Ellis.

Cohen, Nancy (2002). The Reconstruction of American Liberalism: 1865-1914. Chapel Hill, NC: University of North Carolina Press.

Craig, Gordon A. (1978). Germany, 1866-1945. New York: Oxford University Press.

DeMarco, Joseph P. (1974). The Rationale and Foundation of Du Bois's Theory of Economic Cooperation. Phylon, 35(1): 5-15.

Dimand, Robert W. (2005). Economists and the Shadow of "The Other" before 1914. American Fournal of Economics and Sociology, 64(3): 827-851.

Dorfman, Joseph (1934). Thorstein Veblen and His America. New York: Viking.

Dorfman, Joseph (1955). The Role of the German Historical School in American Economic Thought. American Economic Review, 45 (2): 17-28.

Du Bois, W. E. B. (1898a). The Negroes of Farmville, Virginia: A Social Study. Bulletin of the Department of Labor, 14( January): 1-38.

Du Bois, W. E. B. (1898b). The Study of the Negro Problems. Annals of the American Academy of Political and Social Science, 11 (January): 1-23.

Du Bois, W. E. B. (1899). The Negroes in the Black Belt: Some Social Sketches. Bulletin of the Department of Labor, no. 22(May): 401-417.

Du Bois, W. E. B. ([1899] 1973). The Philadelphia Negro: A Social Study. Millwood, NY: Kraus-Thomson.

Du Bois, W. E. B. (1901). The Negro Landholder of Georgia. Bulletin of the Department of Labor, no. 35 ( July): 647-777.

Du Bois, W. E. B. ([1903] 1999). The Souls of Black Folk. Eds. Henry Louis Gates, Jr., and Terri Hume Oliver. New York: W. W. Norton.

Du Bois, W. E. B. (1906). The Economic Future of the Negro. Publications of the American Economic Association, 3rd. ser. 7(1): 219-242.

Du Bois, W. E. B. (Ed.) ([1907] 1969). Economic Co-operation among Negro Americans. New York: Arno.

Du Bois, W. E. B. (1910). Reconstruction and Its Benefits. American Historical Review, 15 (4): 781-799.

Du Bois, W. E. B. (1912). The Rural South. Publications of the American Statistical Association, 13(97): 80-84.

Du Bois, W. E. B. ([1968] 2007). The Autobiography of W. E. B. Du Bois. New York: Oxford University Press.

Edwards, Barrington S. (2006). W. E. B. Du Bois between Worlds: Berlin, Empirical Social Research, and the Race Question. Du Bois Review, 3(2): 395-424.

Ely, Richard T. (1883). The Past and the Present of Political Economy. Overland Monthly, 2(9): 225-235.

Furner, Mary O. (1975). Advocacy and Objectivity: A Crisis in the Professionalization of American Social Science, 1865-1905. Lexington, KY: University Press of Kentucky. 
Gabbidon, Shaun L. (1999). W. E. B. Du Bois and the "Atlanta School" of Social Scientific Research, 1897-1913. Fournal of Criminal Fustice Education, 10(1): 21-38.

Gordon, Lewis R. (2000). Du Bois's Humanistic Philosophy of Human Sciences. Annals of the American Academy of Political and Social Science, 568(March): 265-280.

Grossman, Jonathan (1974). Black Studies in the Department of Labor, 1897-1907. Montbly Labor Review, 97 (6): 17-27.

Katz, Michael B., and Thomas J. Sugrue (2001). The Context of The Philadelphia Negro: The City, the Settlement House Movement, and the Rise of the Social Sciences. In Harold Bloom (Ed.), W. E. B. Du Bois. Bloom's Modern Critical Views, pp. 177-209. Philadelphia, PA: Chelsea House.

Leslie, Thomas Edward Cliffe ([1880] 1888). Political Economy in the United States. In Essays in Political Economy, 2nd ed., pp. 126-154. London: Dublin, Hodges, Figgis.

Lewis, David Levering (1993). W. E. B. Du Bois: Biography of a Race, 1868-1919. New York: Henry Holt.

Marshall, Alfred (1890). Principles of Economics. London: Macmillan.

Mote, Jonathon (1997). (Dis) trusting the Tale: Werner Sombart and the Narrative of Economics. In James P. Henderson (Ed.), The State of the History of Economics: Proceedings of the History of Economics Society, pp. 143-156. New York: Routledge.

Prasch, Robert E. (2004). One Hundred Years of American Economists on Race and Discrimination, 1881-1981. In David Colander, Robert E. Prasch, and Falguni A. Sheth (Eds.), Race, Liberalism and Economics, pp. 145-181. Ann Arbor, MI: University of Michigan Press.

Prasch, Robert E. (2006). "Free Entry and Exit" from the Market: Simplifying or Substantive Assumption? Fournal of Economic Issues, 40(2): 317-323.

Prasch, Robert E. (2007). Professor Lester and the Neoclassicals: The "Marginalist Controversy" and the Postwar Academic Debate over Minimum Wage Legislation: 1945-1950. Fournal of Economic Issues, 41(3): 809-825.

Ransom, Roger L., and Richard Sutch (2001). One Kind of Freedom: The Economic Consequences of Emancipation. New York: Cambridge University Press.

Reed, Adolph L., Jr. (1985). W. E. B. Du Bois: A Perspective on the Bases of His Political Thought. Political Theory, 13(3): 431-456.

Rodgers, Daniel T. (1998). Atlantic Crossings: Social Politics in a Progressive Age. Cambridge, MA: Harvard University Press.

Rutherford, Malcolm (2000). Understanding Institutional Economics: 1918-1929. Fournal of the History of Economic Thought, 22(3): 277-308.

Schafer, Axel R. (2001). W. E. B. Du Bois, German Social Thought, and the Racial Divide in American Progressivism, 1892-1909. Journal of American History, 88(3): 925-949.

Schmoller, Gustav (1894). The Idea of Justice in Political Economy. Trans. Ernest L. von Halle and Carl L. Schutz. Annals of the American Academy of Political and Social Science, 4(March): $1-41$.

Seager, Henry Rogers (1893). Economics at Berlin and Vienna. Fournal of Political Economy, 1(2): 236-262.

Sinclair, Upton (1923). The Goose-Step: A Study of American Education. Pasadena, CA: Self-published.

Sklar, Kathryn Kish (1998). Hull-House Maps and Papers: Social Science as Women's Work in the 1890s. In Helene Silverberg (Ed.). Gender and American Social Science: The Formative Years, pp. 127-155. Princeton, NJ: Princeton University Press.

Small, Albion (1924). Some Contributions to the History of Sociology: Section XV. The Restoration of Ethics in Economic Theory. The Professorial Socialists. The Verein Für Socialpolitik. American Fournal of Sociology, 29(6): 707-725.

Sombart, Werner ([1929] 1991). Economic Theory and Economic History. Fournal of Institutional Economics, 2(1): 109-125.

Steinfeld, Robert J. (2001). Coercion, Contract, and Free Labor in the Nineteenth Century. New York: Cambridge University Press.

Taussig, Frank W. (1905). Schmoller on Protection and Free Trade. Quarterly fournal of Economics, 19(3): 501-511.

Wagner, Adolf (1891). Marshall's Principles of Economics. Quarterly fournal of Economics, 5 (3): 319-338.

Washington, Booker T. ([1895] 1965). The Atlanta Exposition Address, 1895. In Up from Slavery, pp. 147-157. New York: Avon Books.

Yonay, Yuval P. (1998). The Struggle over the Soul of Economics: Institutional and Neoclassical Economists in America between the Wars. Princeton, NJ: Princeton University Press. 